\title{
Effect of Different Integrated Approaches of Organic and Inorganic Fertilization on Growth of Onion (Allium cepa L.)
}

\author{
Santosh Kumar Maida, S. S. Singh, Mahendra Jadia* and Krapal Singh Verma \\ Mahatma Gandhi Chitrakoot Gramodaya Vishwa Vidyalaya, Chitrakoot, District Satna, \\ Madhya Pradesh, India \\ *Corresponding author
}

\begin{abstract}
A B S T R A C T
Keywords

FYM, Treatment, Plant, Stages

Article Info

Accepted:

17 January 2021

Available Online:

10 February 2021

The experiment was carried out to find out the effect of organic, inorganic sources of nutrients on growth of Garlic. The treatment combinations involving three levels of organic manure i.e. $\mathrm{O}_{1}$ - FYM (farm yard manure@20.t/ha, $\mathrm{O}_{2}$-Vermicompost@10.t/ha, $\mathrm{O}_{3}$-Poultry manure@05.t/ha, three levels of In-organic fertilizer i.e. $\mathrm{I}_{1}$ - Control, $\mathrm{I}_{2}-100 \%$ RDF (NPK-150:80:60), I $\mathrm{I}_{3}-50 \%$ RDF (NPK-75:40:30) and Bio-enhancers in three levels i.e. $\mathrm{B}_{1^{-}}$Panchgavya (45 and $60 \mathrm{DAT}$ ), $\mathrm{B}_{2^{-}}$Jivamrit-500 lit. /ha (with every irrigation), $\mathrm{B}_{3^{-}}$ Bijamrit- seed treatment + seedling treatment. Practices were given in Agrifound Dark Red variety. plant height $(\mathrm{cm})$, number of leaves per plant, leaf area per plant $\left(\mathrm{cm}^{2}\right)$, fresh weight of shoot per plant $(\mathrm{g})$, dry weight of shoot per plant $(\mathrm{g})$, fresh weight of bulb per plant $(\mathrm{g})$, dry weight of bulb per plant $(\mathrm{g})$, chlorophyll content of fresh leaves $(\mathrm{mg} / 100 \mathrm{~g})$.were observed by the maximum at 30,60and 90DAS were observed under the treatment $\mathrm{I}_{2}(100 \%$ RDF (NPK-150:80:60) at all the growth stages.
\end{abstract}

\section{Introduction}

There are many bulb crops grown around the world among which one of the most important bulb crop is Onion. Onion (Allium cepa L., 2n $=16$ ) is from the Amaryllidaceae family and it was originated in the central part of the Asian continent. It is an essential part of almost all the kitchens in the Indian subcontinent. Onion is used in most of the curries prepared in India. It is used in salad, spices, sauces, vegetables etc. In our country it is cultivated as annual crop for the production of Onion bulbs and biennial crop for the production of seeds.
Onion bulb has flesh with concentric scales enclosed in wrapping just like various leaves are wrapped one over the other. These scales are connected to the base through stem disc. The outermost layer has roots in it which is connected to the stem providing nutrients from the soil through various layers to the stem. In general terms it can be said that the bulb is basically the stem.

The edible part of the stem is 'bulb' which grows underground. These bulbs are used as condiments and vegetable. The raw part of this onion plant i.e. green leaves and stem which is whole green plant is used directly in 
various forms. It is called as spring onions. Colourful pink-purple onions are used in salad and cooking. Onion is widely used due to its flavour and health promoting properties.

India earns foreign exchange through onion export. The onion export is mainly to Singapore, Malaysia, Nepal, Bangladesh, Pakistan, Sri lanka, Indonesia, Mauritius, Philippines, Indonesia \& Gulf countries.

Organic fertilizers can also be used for the production of Onion. Natural fertilizers like Farm Yard Manure (FYM), compost and poultry manure are the most commonly used in agriculture. FYM is the extensively used inorganic source of plant nutrient. Poultry manure in the richest source of plant nutrients followed by bio-gas slurry, composts, goat manure and FYM, besides vermin-compost which is rich in nutrients, organic matter, vitamins, microbes and growth promoters. The addition of manures in combination with fertilizers may be helpful to maintain the organic carbon content in soil. Use of chemical fertilizers alone cannot keep the pace with the present time in maintenance of soil health for sustaining the productivity.

Use of Bio-enhancers is a new concept in organic agriculture. The bio enhancers are in common use are Amrit Pani, Bijamrita, Jiwamrita, Panchgavaya, Vermi wash etc. In fact, these are rich source of microbial consortia, macro and micronutrients and plant growth promoting substances including immunity enhancers.

\section{Materials and Methods}

A field experiment on Effect of different integrated approaches of organic and inorganic fertilization on growth of onion (Allium cepa L. ) was carried out during Kharif season 2016 and 2017 at Mahatma Gandhi Chitrakoot Gramodaya Vishwa Vidyalaya, Chitrakoot,
District Satna (M.P.). The research work was conducted in the Factorial Completely Randomized Block Design with three replications. Each replication was comprised of 27 treatment combinations. The treatment combinations involving three levels of organic manure i.e. $\mathrm{O}_{1^{-}} \quad \mathrm{FYM}$ (farm yard manure@20.t/ha, O -Vermicompost@10.t/ha, $\mathrm{O}_{3}$-Poultry manure@05.t/ha, three levels of Inorganic fertilizer i.e. $\mathrm{I}_{1}$ - Control, $\mathrm{I}_{2}-100 \% \mathrm{RDF}$ (NPK-150:80:60), $\quad \mathrm{I}_{3}-50 \% \quad \mathrm{RDF} \quad$ (NPK75:40:30) and Bio-enhancers in three levels i.e. $\mathrm{B}_{1^{-}}$Panchgavya (45 and 60 DAT), $\mathrm{B}_{2^{-}}$ Jivamrit-500 lit. /ha (with every irrigation), $\mathrm{B}_{3^{-}}$ Bijamrit- seed treatment + seedling treatment were given in Agrifound Dark Red variety. The climate of the region is semi-arid and subtropical having extreme winter and summer. During the winter months, the temperature drops down to as low as $2^{\circ} \mathrm{C}$ while in the summer months the temperature extend above $47^{\circ} \mathrm{C}$, hot desiccating winds (Loo) are regular symptom during summers while, there may be infrequent spell of frost during the winter months. The soil of the investigation field was clay loam with good drainage and uniform texture with medium NPK status. Observations were recorded according to standard procedure on plant height $(\mathrm{cm})$, number of leaves per plant, leaf area per plant $\left(\mathrm{cm}^{2}\right)$, fresh weight of shoot per plant $(\mathrm{g})$, dry weight of shoot per plant $(\mathrm{g})$, fresh weight of bulb per plant $(\mathrm{g})$, dry weight of bulb per plant $(\mathrm{g})$, chlorophyll content of fresh leaves $(\mathrm{mg} / 100 \mathrm{~g})$.

\section{Results and Discussion}

Among growth parameters, plant height $(\mathrm{cm})$, number of leaves per plant, leaf area per plant $\left(\mathrm{cm}^{2}\right)$, fresh weight of shoot per plant $(\mathrm{g})$, dry weight of shoot per plant $(\mathrm{g})$, fresh weight of bulb per plant $(\mathrm{g})$, dry weight of bulb per plant $(\mathrm{g})$ and chlorophyll content of fresh leaves were studies at 30,60 and 90 DAP in onion (Table 1 and 2). 
Significantly maximum plant height were observed under the treatment $\mathrm{O}_{2}$ (Vermicompost@10.t/ha), while the minimum plant height was observed under the treatment $\mathrm{O}_{3}$ (Poultry manure@05.t/ha) at 30, 60 and 90 days after planting, respectively. Vermicompost helps in providing more and balanced amount of different types of nutrients in less time for onion plant than goat manure. The probable reasons for plant height may be sufficient use of organic matter to increase in water holding capacity and nutrient availability. Similar results have been reported by Jayathilake et al., 2003, Reddy and Reddy 2005, Naik et al., 2013, Chavan et al., 2016.

In case of inorganic fertilizer maximum plant height was recorded in $\mathrm{I}_{2}(100 \%$ RDF (NPK150:80:60)), while minimum plant height was recorded in $\mathrm{I}_{1}$ (Control) at 30, 60 and 90 days after planting, respectively. This might be due to application of NPK which are good for proper growth and development of root area of plant. The NPK contribute significantly to the proper growth and development of plant. Nitrogen is the most indispensable of all mineral nutrients for growth and development of the plant as it is the basis of fundamental constituents of all living matter. Phosphorus plays a important role in the photosynthesis it is a constituent of adenosine tri-phosphate (ATP), the energy molecule. Similarly, the role of potassium in stomata operating and thereby governing the entry of $\mathrm{CO}_{2}$ is widely known. Potassium is essential to controlling water property in the plants and in enhancing the drought tolerance. The findings are in close harmony with the result of Jayathilake et al., 2003, Reddy and Reddy 2005, Naik et al.2013, Chavan et al., 2016.

As regards to bio-enhancers, maximum plant height was recorded under $\mathrm{B}_{2}$ (Jivamrit-500 lit./ha with every irrigation), while minimum plant height was recorded under $\mathrm{B}_{3}$ (Bijamrit- seed treatment + seedling treatment) at 30,60 and 90 days after planting, respectively. The probable cause for proper growth of plants and enhancing the height of plants might be due to growth enzymes available in Jivamrit such enzymes act to enhance cell division. The findings are in close harmony with the result of Chadha et al., 2020a, Chadha et al., 2020b, Pathak and Ram 2013, Kumar et al., 2018.

Interaction effect of the different factors was found to significant except the interaction of IxB and OxIxB at 90 days after planting which was non- significant during first year. Interaction effect of the different factors was found to significant at all the stages during second year and pooled.

Significantly maximum number of leaves per plant were observed under the treatment $\mathrm{O}_{2}$ (Vermicompost@10.t/ha), while the minimum number of leaves per plant was observed under the treatment $\mathrm{O}_{3}$ (Poultry manure@05.t/ha) at 30,60 and 90 days after planting, respectively. The probable reasons for increased number of leaves per plant may be due to incorporation of Vermicompost which helps in availability of more and balanced amount of different types of nutrients require for increase number of leaves per plant. The probable reasons for plant height may be ample use of organic matter to increase in water holding capacity and nutrient availability. Similar results have been reported by Jayathilake et al., 2003, Reddy and Reddy 2005, Jawadagi et al., 2012, Chavan et al., 2016.

In case of inorganic fertilizer maximum number of leaves per plant was recorded in $\mathrm{I}_{2}$ (100\% RDF (NPK-150:80:60)), while minimum number of leaves per plant was recorded in $\mathrm{I}_{1}$ (Control) at 30, 60 and 90 days after planting, respectively. A sufficient use of primary nutrients through inorganic 
fertilizers at their recommended doses might have led to formation of soil solution rich in almost all ions required to be essentially to the plants. It is again an established fact that among other things, the nutrients acquisition power of a plant greatly depends on the concentration of the ions in soil solution. It can therefore, be assumed that the plants growing in the plots with all major nutrients enjoyed a situation congenial for their growth and development. Similar results have been reported by Jayathilake et al., 2003, Reddy and Reddy 2005, Jawadagi et al., 2012, Chavan et al., 2016.

As regards to bio-enhancers, maximum number of leaves per plant was recorded under $\mathrm{B}_{2}$ (Jivamrit-500 lit. /ha with every irrigation), while minimum number of leaves per plant was recorded under $\mathrm{B}_{3}$ (Bijamritseed treatment + seedling treatment) at 30,60 and 90 days after planting, respectively. The possible reason for this may be due to effective micro organism (EMO) cultures in Jivamrit could synthesize phytohormones i.e., auxins and other growth regulators that stimulated plant growth. Jiwamrita is rich source of macro, micro nutrients, Trichoderma, Pseudomonas, nitrogen fixers and phosphate solublizers.Jivamrit which colonize in the leaves increase the ammonia uptake and boost total nitrogen supply which are stimulated in number of leaves per plant. The findings are in close harmony with the result of Chadha et al., 2020a, Chadha et al., 2020b, Pathak and Ram 2013, Kumar et al., 2018.

Interaction effect of the different factors was found to significant except the interaction of OxI, IxB, BxO and OxIxB at 60 days after planting which was non significant during first year. Interaction effect of the different factors was found to significant except the interaction of $\mathrm{OxI}, \mathrm{IxB}, \mathrm{BxO}$ and $\mathrm{OxIxB}$ at 30 days after planting and $\mathrm{IxB}, \mathrm{BxO}$ at 60 during second year. Interaction effect of the different factors was found to significant except the interaction of $\mathrm{IxB}$ and $\mathrm{BxO}$ at 30 days after planting and $\mathrm{IxB}$ and $\mathrm{BxO}$ and $\mathrm{OxIxB}$ at 60 days after planting which was non-significant pooled.

Significantly maximum leaf area per plant were observed under the treatment $\mathrm{O}_{2}$ (Vermicompost@10.t/ha), while the minimum leaf area per plant was observed under the treatment $\mathrm{O}_{3}$ (Poultry manure@05.t/ha) at 30,60 and 90 days after planting, respectively. The probable reasons for increased leaf area per plant may be due to cumulative effect of continuous supply of nutrients, vitamins and growth promoting substances available in vermicompost which ultimately lead to boost cell division. These results were in close conformity with the findings of Reddy and Reddy 2005, Jawadagi et al., (2012).

In case of inorganic fertilizer maximum leaf area per plant was recorded in $\mathrm{I}_{2}[100 \% \mathrm{RDF}$ (NPK-150:80:60)], while minimum leaf area per plant was recorded in $\mathrm{I}_{1}$ (Control) at 30 , 60 and 90 days after planting, respectively. A sufficient use of primary nutrients through inorganic fertilizers at their recommended doses might have led to formation of soil solution rich in almost all ions required to be essentially to the plants. It is again an established fact that among other things, the nutrients acquisition power of a plant greatly depends on the concentration of the ions in soil solution. It can therefore, be assumed that the plants growing in the plots with all major nutrients enjoyed a situation congenial for their growth and development. Similar results have been reported by Reddy and Reddy 2005, Jawadagi et al., 2012.

As regards to bio-enhancers, maximum leaf area per plant was recorded under $\mathrm{B}_{2}$ (Jivamrit-500 lit./ha with every irrigation), 
while minimum leaf area per plant was recorded under $\mathrm{B}_{3}$ (Bijamrit- seed treatment + seedling treatment) at 30,60 and 90 days after planting, respectively. The possible reason for this may be due to effective micro organism (EMO) cultures in Jivamrit could synthesize phytohormones i.e., auxins and other growth regulators that stimulated plant growth. Jiwamrita is rich source of macro, micro nutrients, Trichoderma, Pseudomonas, nitrogen fixers and phosphate solublizers. Jivamrit which colonize in the leaves increase the ammonia uptake and boost total nitrogen supply which is stimulated in leaf area per plant. The findings are in close harmony with the result of Chadha et al., 2020a, Chadha et al., 2020b, Pathak and Ram 2013, Kumar et al., 2018.

Interaction effect of the different factors was found to significant at all the stages during both the years and pooled.

Significantly maximum fresh weight of shoot per plant were observed under the treatment $\mathrm{O}_{2}$ (Vermicompost@10.t/ha), while the minimum fresh weight of shoot per plant was observed under the treatment $\mathrm{O}_{3}$ (Poultry manure@05.t/ha) at 30,60 and 90 days after planting, respectively. The probable reason may be due to continues supply of primary and secondary nutrients through vermicompost leads to enhanced fresh weight of shoot per plant. These results were corroborated with the findings of Pachauri et al., (2005), Patidar et al., (2019).

In case of inorganic fertilizer maximum fresh weight of shoot per plant was recorded in $\mathrm{I}_{2}$ [100\% RDF (NPK-150:80:60)], while minimum fresh weight of shoot per plant was recorded in $\mathrm{I}_{1}$ (Control) at 30, 60 and 90 days after planting, respectively. This may be due to use of macro and micro nutrients, enhanced the photosynthetic activity, chlorophyll formation, nitrogen metabolism and auxin amount in the plants which increasing the plant growth finally fresh weight of shoot per plant. The findings are also in agreement with the findings of Pachauri et al., 2005, Patidar et al., (2019).

As regards to bio-enhancers, maximum fresh weight of shoot per plant was recorded under $\mathrm{B}_{2}$ (Jivamrit-500 lit. /ha with every irrigation), while minimum fresh weight of shoot per plant was recorded under $\mathrm{B}_{3}$ (Bijamrit- seed treatment + seedling treatment) at 30,60 and 90 days after planting, respectively. Jivamrit combination is adjudged as the best organic nutrition practice for sustainability by its overall performance on growth, productivity, quality of crops. These results were corroborated with the findings of Chadha et al., 2020a, Chadha et al., 2020b, Pathak and Ram 2013, Kumar et al., 2018.

Interaction effect of the different factors was found to significant at all the stages during first year. Interaction effect of the different factors was found to significant except the interaction of $\mathrm{IxB}, \mathrm{BxO}$ and $\mathrm{OxIxB}$ at 90 days after planting which was non- significant during second year. Interaction effect of the different factors was found to significant except the interaction of $\mathrm{IxB}$ and $\mathrm{BxO}$ at 90 days after planting which was non- significant in pooled.

Significantly maximum dry weight of shoot per plant were observed under the treatment $\mathrm{O}_{2}$ (Vermicompost@10.t/ha), while the minimum dry weight of shoot per plant was observed under the treatment $\mathrm{O}_{3}$ (Poultry manure@05.t/ha) at 30, 60 and 90 days after planting, respectively. The probable reason may be due to continues supply of primary and secondary nutrients through vermicompost leads to enhanced dry weight of shoot per plant. These results were corroborated with the findings of Jawadagi et al., (2012). 
Table.1 Effect of different integrated approaches of organic and inorganic fertilization on plant height (cm), number of leaves per plant, leaf area per plant $\left(\mathrm{cm}^{2}\right)$, fresh weight of shoot per plant $(\mathrm{g})$ of onion

\begin{tabular}{|c|c|c|c|c|c|c|c|c|c|c|c|c|}
\hline \multirow[t]{2}{*}{$\begin{array}{c}\text { Treatment } \\
\text { Symbols }\end{array}$} & \multicolumn{3}{|c|}{ Plant height (cm) } & \multicolumn{3}{|c|}{ Number of leaves per plant } & \multicolumn{3}{|c|}{ Leaf area per plant $\left(\mathrm{cm}^{2}\right)$} & \multicolumn{3}{|c|}{$\begin{array}{c}\text { Fresh weight of shoot per } \\
\text { plant (g) }\end{array}$} \\
\hline & 30 DAS & 60 DAS & 90 DAS & 30 DAS & 60 DAS & 90 DAS & 30 DAS & 60 DAS & 90 DAS & 30 DAS & 60 DAS & 90 DAS \\
\hline $\mathbf{O}_{1}$ & 36.854 & 41.637 & 45.373 & 14.779 & 17.858 & 18.925 & 105.103 & 129.834 & 142.68 & 18.842 & 21.056 & 27.702 \\
\hline $\mathbf{O}_{2}$ & 37.685 & 42.496 & 46.919 & 15.357 & 18.386 & 19.391 & 108.871 & 134.499 & 147.796 & 19.551 & 21.8 & 28.599 \\
\hline $\mathrm{O}_{3}$ & 33.588 & 40.859 & 43.891 & 13.093 & 16.371 & 17.603 & 86.947 & 101.73 & 115.982 & 15.654 & 17.783 & 24.468 \\
\hline SEm \pm & 0.013 & 0.021 & $\mathbf{0 . 0 3 3}$ & 0.061 & 0.072 & 0.023 & 0.039 & 0.034 & 0.053 & 0.037 & 0.035 & 0.087 \\
\hline $\mathrm{CD}_{5 \%}$ & 0.038 & 0.059 & 0.094 & 0.172 & 0.203 & 0.067 & 0.11 & 0.095 & 0.149 & 0.104 & 0.1 & 0.246 \\
\hline $\mathbf{I}_{1}$ & 32.710 & 40.393 & 43.078 & 12.655 & 16.001 & 17.259 & 84.274 & 96.995 & 111.4 & 14.716 & 16.831 & 23.524 \\
\hline $\mathbf{I}_{2}$ & 38.895 & 42.598 & 47.152 & 16.118 & 19.073 & 20.006 & 116.064 & 145.294 & 157.336 & 21.036 & 23.327 & 30.141 \\
\hline $\mathbf{I}_{3}$ & 36.522 & 42.000 & 45.953 & 14.455 & 17.541 & 18.653 & 100.583 & 123.774 & 137.722 & 18.295 & 20.481 & 27.105 \\
\hline SEm \pm & 0.013 & 0.021 & 0.033 & 0.061 & 0.072 & 0.023 & 0.039 & 0.034 & 0.053 & $\mathbf{0 . 0 3 7}$ & 0.035 & 0.087 \\
\hline $\mathrm{CD}_{5 \%}$ & 0.038 & 0.059 & 0.094 & 0.172 & 0.203 & 0.067 & 0.11 & 0.095 & 0.149 & 0.104 & 0.1 & 0.246 \\
\hline $\mathbf{B}_{1}$ & 35.892 & 41.928 & 45.827 & 14.298 & 17.446 & 18.553 & 100.199 & 121.495 & 135.21 & 18.102 & 20.296 & 27.031 \\
\hline $\mathbf{B}_{2}$ & 37.12 & 44.675 & 50.659 & 14.980 & 18.052 & 19.095 & 104.885 & 129.55 & 142.271 & 18.816 & 21.051 & 27.809 \\
\hline $\mathbf{B}_{3}$ & 35.115 & 38.389 & 39.697 & 13.951 & 17.117 & 18.271 & 95.837 & 115.018 & 128.978 & 17.129 & 19.291 & 25.929 \\
\hline $\mathrm{SEm} \pm$ & 0.013 & 0.021 & 0.033 & 0.061 & 0.072 & 0.023 & 0.039 & 0.034 & 0.053 & 0.037 & 0.035 & 0.087 \\
\hline
\end{tabular}


Table.2 Effect of different integrated approaches of organic and inorganic fertilization on dry weight of shoot per plant ( $\mathrm{g}$ ), fresh weight of bulb per plant (g), dry weight of bulb per plant (g), chlorophyll content of fresh leaves (mg/100g)of onion

\begin{tabular}{|c|c|c|c|c|c|c|c|c|c|c|c|c|}
\hline \multirow[t]{2}{*}{$\begin{array}{l}\text { Treatment } \\
\text { Symbols }\end{array}$} & \multicolumn{3}{|c|}{$\begin{array}{c}\text { Dry weight of shoot per plant } \\
(\mathrm{g})\end{array}$} & \multicolumn{3}{|c|}{$\begin{array}{c}\text { Fresh weight of bulb per } \\
\text { plant (g) }\end{array}$} & \multicolumn{3}{|c|}{$\begin{array}{c}\text { Dry weight of bulb per plant } \\
\text { (g) }\end{array}$} & \multicolumn{3}{|c|}{$\begin{array}{c}\text { Chlorophyll content of fresh } \\
\text { leaves }(\mathrm{mg} / \mathbf{1 0 0 g})\end{array}$} \\
\hline & 30 DAS & 60 DAS & 90 DAS & 30 DAS & 60 DAS & 90 DAS & 30 DAS & 60 DAS & 90 DAS & 30 DAS & 60 DAS & 90 DAS \\
\hline $\mathbf{O}_{1}$ & 0.913 & 2.461 & 3.738 & 7.279 & 18.833 & 108.555 & 5.831 & 14.346 & 20.286 & 1.431 & 1.792 & 1.726 \\
\hline $\mathrm{O}_{2}$ & 1.021 & 2.654 & 3.908 & 7.566 & 19.199 & 108.928 & 6.083 & 14.506 & 20.775 & 1.561 & 1.955 & 1.796 \\
\hline $\mathrm{O}_{3}$ & 0.564 & 1.687 & 2.94 & 6.23 & 17.027 & 106.659 & 4.769 & 13.819 & 17.686 & 1.164 & 1.436 & 1.484 \\
\hline SEm \pm & 0.036 & 0.072 & 0.036 & 0.073 & 0.073 & 0.062 & 0.077 & 0.04 & 0.028 & 0.036 & 0.036 & 0.036 \\
\hline $\mathrm{CD}_{5 \%}$ & 0.103 & 0.204 & 0.103 & 0.206 & 0.207 & 0.177 & 0.22 & 0.113 & 0.081 & 0.103 & 0.102 & 0.103 \\
\hline$I_{1}$ & 0.529 & 1.544 & 2.759 & 6.108 & 16.584 & 106.233 & 4.581 & 13.738 & 17.258 & 1.143 & 1.375 & 1.432 \\
\hline $\mathbf{I}_{2}$ & 1.185 & 3.034 & 4.326 & 8.047 & 19.894 & 109.653 & 6.54 & 14.754 & 21.614 & 1.676 & 2.122 & 1.919 \\
\hline$I_{3}$ & 0.784 & 2.225 & 3.5 & 6.92 & 18.581 & 108.257 & 5.562 & 14.179 & 19.876 & 1.337 & 1.687 & 1.655 \\
\hline SEm \pm & 0.036 & 0.072 & 0.036 & 0.073 & 0.073 & 0.062 & 0.077 & 0.04 & 0.028 & 0.036 & 0.036 & 0.036 \\
\hline $\mathrm{CD}_{5 \%}$ & 0.103 & 0.204 & 0.103 & 0.206 & 0.207 & 0.177 & 0.22 & 0.113 & 0.081 & 0.103 & 0.102 & 0.103 \\
\hline $\mathbf{B}_{1}$ & 0.83 & 2.224 & 3.532 & 7.04 & 18.33 & 108.039 & 5.549 & 14.216 & 19.619 & 1.386 & 1.732 & 1.673 \\
\hline $\mathbf{B}_{2}$ & 0.939 & 2.525 & 3.76 & 7.314 & 18.843 & 108.553 & 5.863 & 14.388 & 20.258 & 1.483 & 1.872 & 1.747 \\
\hline $\mathbf{B}_{3}$ & 0.728 & 2.054 & 3.294 & 6.721 & 17.887 & 107.55 & 5.271 & 14.067 & 18.87 & 1.287 & 1.58 & 1.587 \\
\hline $\mathrm{SEm} \pm$ & 0.036 & 0.072 & 0.036 & 0.073 & 0.073 & 0.062 & 0.077 & 0.04 & 0.028 & 0.036 & 0.036 & 0.036 \\
\hline $\mathrm{CD}_{5 \%}$ & 0.103 & 0.204 & 0.103 & 0.206 & 0.207 & 0.177 & 0.22 & 0.113 & 0.081 & 0.103 & 0.102 & 0.103 \\
\hline
\end{tabular}


In case of inorganic fertilizer maximum dry weight of shoot per plant was recorded in $\mathrm{I}_{2}[100 \% \quad \mathrm{RDF} \quad$ (NPK-150:80:60)], while minimum dry weight of shoot per plant was recorded in $\mathrm{I}_{1}$ (Control) at 30, 60 and 90 days after planting, respectively. This may be due to use of macro and micro nutrients, enhanced the photosynthetic activity, chlorophyll formation, nitrogen metabolism and auxin amount in the plants which increasing the plant growth finally dry weight of shoot per plant. The findings are also in agreement with the findings of Jawadagi et al., (2012).

As regards to bio-enhancers, maximum dry weight of shoot per plant was recorded under $\mathrm{B}_{2}$ (Jivamrit-500 lit. /ha with every irrigation), while minimum dry weight of shoot per plant was recorded under $\mathrm{B}_{3}$ (Bijamrit- seed treatment + seedling treatment) at 30,60 and 90 days after planting, respectively. Jivamrit combination is adjudged as the best organic nutrition practice for sustainability by its overall performance on growth, productivity, quality of crops. These results were corroborated with the findings of Chadha et al., (2020a), Chadha et al., (2020b), Pathak and Ram (2013), Kumar et al., (2018).

Interaction effect of the different factors was found to significant except the interaction of OxIxB at 60 days after planting which was nonsignificant during first year. Interaction effect of the different factors was found to significant except the interaction of $\mathrm{OxI}, \mathrm{IxB}, \mathrm{BxO}$ and OxIxB at 30 days after planting, OxIxB at 60 and 90 days after planting which was nonsignificant during second year. Interaction effect of the different factors was found to significant except the interaction of $\mathrm{IxB}, \mathrm{BxO}$ and OxIxB at 30,60 and 90 days after planting which was non-significant pooled.

Significantly maximum fresh weight of bulb per plant were observed under the treatment $\mathrm{O}_{2}$ (Vermicompost @ 10.t/ha),while the minimum fresh weight of bulb per plant was observed under the treatment $\mathrm{O}_{3}$ (Poultry manure @ 05.t/ha) at 30, 60 and 90 days after planting, respectively. The probable reason may be due to continues supply of primary and secondary nutrients through vermicompost leads to enhanced fresh weight of bulb per plant. These results were corroborated with the findings of Pachauri et al., (2005), Patidar et al., (2019).

In case of inorganic fertilizer maximum fresh weight of bulb per plant was recorded in $\mathrm{I}_{2}(100 \%$ RDF (NPK-150:80:60)), while minimum fresh weight of bulb per plant was recorded in $I_{1}$ (Control) at 30,60 and 90 days after planting, respectively. This may be due to use of macro and micro nutrients, enhanced the photosynthetic activity, chlorophyll formation, nitrogen metabolism and auxin amount in the plants which increasing the plant growth finally fresh weight of bulb per plant. The findings are also in agreement with the findings of Pachauri et al., (2005), Patidar et al., (2019).

As regards to bio-enhancers, maximum fresh weight of bulb per plant was recorded under $\mathrm{B}_{2}$ (Jivamrit-500 lit. /ha with every irrigation), while minimum fresh weight of bulb per plant was recorded under $\mathrm{B}_{3}$ (Bijamrit- seed treatment + seedling treatment) at 30,60 and 90 days after planting, respectively. Jivamrit combination is adjudged as the best organic nutrition practice for sustainability by its overall performance on growth, productivity, quality of crops. These results were corroborated with the findings of Chadha et al., (2020a), Chadha et al., (2020b), Pathak and Ram (2013), Kumar et al., (2018).

Interaction effect of the different factors was found to significant except the interaction of $\mathrm{IxB}, \mathrm{BxO}$ and $\mathrm{OxIxB}$ at 60 and 90 days after planting which was non- significant during first year. Interaction effect of the different factors was found to significant except the interaction of $\mathrm{IxB}, \mathrm{BxO}$ and $\mathrm{OxIxB}$ at 30,60 and 90 days after planting which was non-significant during second year and pooled.

Significantly maximum dry weight of bulb per plant were observed under the treatment $\mathrm{O}_{2}$ (Vermicompost@10.t/ha), while the minimum dry weight of bulb per plant was observed under the treatment $\mathrm{O}_{3}$ (Poultry manure@05.t/ha) at 
30, 60 and 90 days after planting, respectively. The probable reason may be due to continues supply of primary and secondary nutrients through vermicompost leads to enhanced dry weight of bulb per plant. These results were corroborated with the findings of Jayathilake et al., (2003), Jawadagi et al., (2012).

In case of inorganic fertilizer maximum dry weight of bulb per plant was recorded in $\mathrm{I}_{2}(100 \%$ RDF (NPK-150:80:60)), while minimum dry weight of bulb per plant was recorded in $\mathrm{I}_{1}$ (Control) at 30,60 and 90 days after planting, respectively. This may be due to use of macro and micro nutrients, enhanced the photosynthetic activity, chlorophyll formation, nitrogen metabolism and auxin amount in the plants which increasing the plant growth finally dry weight of bulb per plant. The findings are also in agreement with the findings of Jayathilake et al., (2003), Jawadagi et al., (2012).

As regards to bio-enhancers, maximum dry weight of bulb per plant was recorded under $\mathrm{B}_{2}$ (Jivamrit-500 lit. /ha with every irrigation), while minimum dry weight of bulb per plant was recorded under $\mathrm{B}_{3}$ (Bijamrit- seed treatment + seedling treatment) at 30,60 and 90 days after planting, respectively. Jivamrit combination is adjudged as the best organic nutrition practice for sustainability by its overall performance on growth, productivity, quality of crops. These results were corroborated with the findings of Chadha et al., (2020a), Chadha et al., (2020b), Pathak and Ram (2013) and Kumar et al., (2018).

Interaction effect of the different factors was found to significant except the interaction of $\mathrm{IxB}, \mathrm{BxO}$ and $\mathrm{OxIxB}$ at 30 days after planting and $\mathrm{OxI}, \mathrm{IxB}, \mathrm{BxO}$ and $\mathrm{OxIxB}$ at 60 days after planting which was non-significant. Interaction effect of the different factors was found to significant except the interaction of OxI, IxB, $\mathrm{BxO}$ and OxIxB at 30 and 60 days after planting which was non-significant. interaction effect of the different factors was found to significant except the interaction of OxI, IxB,
$\mathrm{BxO}$ and $\mathrm{OxIxB}$ at 30 days after planting and OxIxB at 60 days after planting which was nonsignificant.

Significantly maximum chlorophyll content of fresh leaves were observed under the treatment $\mathrm{O}_{2}$ (Vermicompost@10.t/ha), while the minimum chlorophyll content of fresh leaves was observed under the treatment $\mathrm{O}_{3}$ (Poultry manure@05.t/ha) at 30,60 and 90 days after planting, respectively. The probable reason may be due to continues supply of primary and secondary nutrients through vermicompost leads to enhanced chlorophyll content of fresh leaves. The findings are also in agreement with the findings of Jayathilake et al., (2003), Jawadagi et al., (2012).

In case of inorganic fertilizer maximum chlorophyll content of fresh leaves was recorded in $I_{2}(100 \%$ RDF (NPK-150:80:60)), while minimum chlorophyll content of fresh leaves was recorded in $I_{1}$ (Control) at 30, 60 and 90 days after planting, respectively. Adequate absorption of key nutrients leads to ample growth and development of plants due to which more chlorophyll is produced in the leaves. The findings are also in agreement with the findings of Jayathilake et al., (2003), Jawadagi et al., (2012).

As regards to bio-enhancers, maximum chlorophyll content of fresh leaves was recorded under $\mathrm{B}_{2}$ (Jivamrit-500 lit. /ha with every irrigation), while minimum chlorophyll content of fresh leaves was recorded under $\mathrm{B}_{3}$ (Bijamrit- seed treatment + seedling treatment) at 30, 60 and 90 days after planting, respectively. Different types of beneficial bacteria available in Jivamrit and hormones produced as a result of their activity, leads to proper growth of plants. Chadha et al., (2020a), Chadha et al., (2020b), Pathak and Ram (2013), Kumar et al., (2018).

Interaction effect of the different factors was found to significant except the all interaction at 60 days after planting which was nonsignificant during first year. Interaction effect of 
the different factors was found to significant except the interaction of $\mathrm{OxI}, \mathrm{IxB}, \mathrm{BxO}$ and OxIxB at30,60and 90 days after planting which was non-significant during second year. Interaction effect of the different factors was found to significant except the interaction of $\mathrm{IxB}, \mathrm{BxO}$ and $\mathrm{OxIxB}$ at 30 days after planting and $\mathrm{OxI}, \mathrm{IxB}, \mathrm{BxO}$ and $\mathrm{OxIxB}$ at 60and 90 days after planting which was non-significant.

\section{References}

Chadha, S., Rameshwar, Ashlesha, Saini, J.P. and Paul, Y.S. (2012a). Vedic Krishi: Sustainable livelihood option for small and marginal farmers.Indian Journal of Traditional Knowledge Vol. 11 (3),July 2012,: 480-486.

Chadha, S., Rameshwar, Ashlesha, Saini, J.P. and Paul, Y.S. (2012b). Vedic Krishi: Sustainable livelihood option for small and marginal farmers. Indian Journal of Traditional Knowledge Vol. 11 (3),July 2012,: 480-486.

Chavan D. L., Chavan N. H. and Choudhary, S. M. (2016). Effect of different organic manures on growth and yield of onion (Allium cepa L.). The bioscan. 11(4): 2529-2532.

Jayathilake, P. K. S., Reddy, I. P., Srihari, D., Reddy, K. R. and Neeraja, G. (2003). Integrated Nutrient Management in onion (Allium cepa L.). Tropical Agricultural Research, 15:1-9.

Jawadagi, R. S. Basavaraj N., Hemla B., Naik, B. Patil N. and Channappagoudar, B. B. (2012). Effect of planting geometry and organic sources of nutrients on growth, yield and quality of rabionion Cv. Bellary red. Karnataka J. Agric. Sci., 25 (2):
(236-240).

Kumar Sharvan, Trivedi Himanshu, Sah Rahul, Verma Amit Kumar and Atul Yadav (2018). Effect of different bio-enhancers on growth \& yield of cauliflower (Brassica oleracea L. Var. Botrytis). Journal of Pharmacognosy and Phytochemistry; SP 1: 769-772.

Naik, B.H. and Hosamani, R. M. (2013). Effect of spacings and nitrogen levels on growth and yield of kharif onion. Karnataka Journal of Agricultural Sciences, 16 (1): 98-102.

Pachauri,S.P., Singh,Vinay and Pachauri, C.P. (2005). Influence of nitrogen and sulphur application on growth and yield of onion. In: National Seminar on Agrotechnology, Quality, Processing and Export of Spices J.N.K.V.V. Jabalpur. pp: 68.

Pathak R.K. and Ram, R.A. (2013). Bioenhancers: A potential tool to improve soil fertility, plant health in organic production of horticultural crops Progressive Horticulture, Vol. 45, No. 2, 237-254.

Patidar Ankit, Kumar Raviendra, Kumar Uday and Indra Kumar Kemro(2019). A studies on the effect of different organic sources on onion (Allium cepaL.) productivity and soil health Journal of Pharmacognosy and Phytochemistry 2019; 8(3): 1069-1072.

Reddy, K.C. and Reddy, K.M. (2005). Differential levels of vermicompost and nitrogen on growth and yield in onion (Allium cepa L.) - radish (Raphanus sativus L.) cropping system. Journal of Research ANGRAU. 33 (1): 11-17.

\section{How to cite this article:}

Santosh Kumar Maida, SS. Singh, Mahendra Jadia and Krapal Singh Verma. 2021. Effect of Different Integrated Approaches of Organic and Inorganic Fertilization on Growth of Onion (Allium cepa L.). Int.J.Curr.Microbiol.App.Sci. 10(02): 2303-2312. doi: https://doi.org/10.20546/ijcmas.2021.1002.274 